Konrad Wnęk

Kraków

\title{
Franciszek Wasyl, Ormianie w przedautonomicznej Galicji. Studium demograficzno-historyczne, Kraków 2015, ss. 550
}

Wielowiekowe istnienie ormiańskiej populacji w Polsce doczekało się już sporej liczby różnego rodzaju opracowań, lecz rzadko ich autorzy zajmowali się w nich kwestiami demograficznymi. Dlatego publikacja Franciszka Wasyla wzbudziła zainteresowanie szerokiego kręgu historyków, którzy oczekiwali, że będzie to gruntowna monografia odnosząca się do określonego terytorium, w której wykorzystane zostały różnego typu źródła dotychczas pomijane przez badaczy. Uzyskany obraz ormiańskiej wspólnoty nie jest jednak w pełni satysfakcjonujący.

Książka na pierwszy rzut oka wydaje się obszerna - liczy aż 550 stron i zawiera dodatkowo jedną mapę. Samego tekstu jest jednak mniej, bo „tylko” 287 stron; resztę zajmują zdjęcia wykorzystanych źródeł, ich edycja, a także bibliografia, indeksy i spisy tablic, ilustracji i wykresów. Autor zamieścił w publikacji bardzo dobrej jakości zdjęcia samego źródła, a dodatkowo jego edycję, która - należy zaznaczyć - nie jest edycją krytyczną. Brak jest jakiegokolwiek omówienia źródła i jego krytyki w tej części pracy, pozbawiona jest ona także przypisów. Praca składa się ze Wstępu, sześciu rozdziałów merytorycznych: I. Źródła i literatura, II. Ormianie i ich miniaturowa wspólnota, III. Matżeństwo po ormiańsku, IV. Potomstwo, V. Ormiańskie ognisko domowe, VI. Śmierć i pogrzeb, Zakończenia, a następnie wspomnianej edycji źródeł i bibliografii oraz różnych spisów.

W rozdziale I omówione zostały wykorzystane źródła i literatura przedmiotu. Należy przyznać, że zrobiono to bardzo rzetelnie i szczegółowo oraz zamieszczono bogaty materiał ilustracyjny fragmentów źródeł, który pozwolił na wyrobienie 
sobie opinii o ich wartości historycznej. Autor omówił bazę źródłową, do której należały katastry józefiński i franciszkański, różnego rodzaju spisy ludności ormiańskiej, metryki chrztów, ślubów i pogrzebów, materiały kartograficzne itd. Brakuje jednak krytyki dokładności rejestracji ludności w spisach i metrykach, a opinie na temat katastrów gruntowych są nieco chybione. Otóż wbrew twierdzeniom autora metryka józefińska i franciszkańska wcale nie „odnosi się do każdego gospodarstwa domowego" (s. 40), lecz do parceli katastralnej, a co za tym idzie, nie są w nich uwzględnieni ci, którzy nie posiadali własnej nieruchomości. Na wsi zaś było takiej ludności całkiem sporo, istniał cały szereg kategorii komorników, kątników, służby domowej i żebraków, którzy tworzyli gospodarstwa domowe, nie posiadając ziemi.

W przeciwieństwie do omówienia podstawy źródłowej, niedosyt pozostawia znajomość literatury demograficznej. Zignorowanie Ludności nowoczesnego Lwowa w latach 1857-1938 lub Transformacji demograficznej w Galicji wywołuje wrażenie, że autor niektórych prac po prostu nie zna.

Rozdział II, Ormianie i ich miniaturowa wspólnota, rozpoczyna się od analizy geografii zasiedlenia Galicji i choć brakuje tutaj mapy, która ukazałaby ich przestrzenną dystrybucję, to korzystając $z$ tej zamieszczonej na końcu książki, można ją sobie bez większego trudu wyobrazić. Następnie omówiona została liczebność populacji ormiańskiej w Galicji. Ormian było na tym obszarze stosunkowo niewielu - w połowie XIX wieku ich liczba oscylowała pomiędzy 3269 a 3483 osób. W tym punkcie lektury zacząłem się zastanawiać, w jaki sposób zostanie na podstawie tak niewielkiej liczebnie populacji opracowana część statystyczna. Demografia historyczna nie analizuje bowiem poszczególnych jednostek, lecz bierze pod uwagę populację lub jej część, ale musi ona spełniać warunek odpowiedniej liczebności, aby mogło działać prawo wielkich liczb.

Lektura rozdziału III ma dostarczyć wiedzy o Matżeństwie po ormiańsku. Niektóre stwierdzenia w tej części pracy mają charakter deklaratywny, jak w przypadku wiary w to, że dopiero po zawarciu związku małżeńskiego ,panna staje się kobietą, a kawaler mężczyzną - rozpoczynają wspólne życie i jednocześnie tracą na zawsze swoje wcześniejsze walory (dziewczyna przestaje być dziewicą, a chłopak traci swoją niezależność)". Wolałbym na poparcie tej tezy zobaczyć na przykład analizę poczęć przedślubnych niż tylko przypis numer 286, który nawet nie precyzuje, który z cytowanych autorów był zwolennikiem tej wątłej hipotezy. Po omówieniu aspektów prawnych zawierania małżeństwa i przywołaniu kilku egzemplifikacji problemów, z jakimi mogli się zetknąć nupturienci, autor przystąpił do badania zagadnienia zawierania małżeństw, uznając je za „poddające się stosunkowo najłatwiej analizie ściśle demograficznej”. W jej trakcie zaprezentował tablicę statystyczną numer 2 (s. 100), w której wartości względne przekraczają liczbę jednostek statystycznych, zatem 1 małżeństwo to 
2,4\% populacji zawierającej związki małżeńskie w Stanisławowie. Omówienie wieku zawierania małżeństw opiera się na danych z Kut i Stanisławowa, przy czym nigdzie nie sprecyzowano liczebności tych subpopulacji oraz konkretnej liczby przypadków odrzuconych ze względu na braki źródłowe. Dowiadujemy się jedynie, że było ich kilkanaście, choć nie wiemy, czy dotyczy to obu miejscowości. Według moich obliczeń braków danych w przypadku Kut było przynajmniej 21, ponieważ tyle wynosi różnica pomiędzy liczbą panien (461) a liczbą kawalerów (440), mogło być ich nieco więcej ze względu na niewiadomą liczbę wszystkich panien. Obliczony przez autora wiek ,średni” nie został sprecyzowany, ale $z$ analizy danych wynika, że jest to średnia arytmetyczna, zamiast przyjętej od lat w badaniach demograficznych mediany. Inne zasady przyjęte w statystyce i demografii historycznej również zostały zignorowane, jak chociażby zasada podawania najpierw danych dotyczących mężczyzn, a dopiero później kobiet. Nie sposób się też zgodzić z interpretacją, że „,na panny, dla których nie znaleziono męża do dwudziestego roku życia, czekały coraz mniejsze perspektywy korzystnego zamążpójścia”. Autor w żaden sposób nie udowodnił tezy, że zamążpójście we wczesnym wieku było korzystniejsze dla panny młodej; być może te, które dłużej zwlekały z wyjściem za mąż, miały większe szanse wyboru lepszego, czyli najczęściej bogatszego męża. Zresztą w przedziale wieku 15-19 lat w Kutach za mąż wyszło 188 panien, a w przedziale 20-24 lat - 174, więc różnice pomiędzy tymi grupami wiekowymi są minimalne i nie świadczą o wyraźnym preferowaniu bardzo wczesnego wieku zawierania małżeństw. Natomiast zauważalnie spadało prawdopodobieństwo wyjścia za mąż w późniejszych przedziałach wiekowych, istotną barierą było tutaj 30 lat.

Analiza sezonowości zawierania małżeństw ormiańskich pozostawia również wiele do życzenia, a porównywanie trzech obrządków między sobą w różnych latach jest zabiegiem pozbawionym sensu. Jak pisze autor, „,na podstawie dwóch zestawień tabelarycznych (tab. 7 i 8) [prawidłowo powinno być 8 i 9 - K.W.] widać wyraźnie różnice w sezonowości zawierania małżeństw". Szkoda tylko, że porównuje on dane z Brzeżan z lat 1701-1800 oraz Kut dla lat 1780-1848, czyniąc to $w$ dodatku nieprawidłowo. Błąd metodologiczny młodego adepta demografii historycznej polega na tym, że dane dotyczące Brzeżan zaczerpnął z podręcznika Cezarego Kukli, które występują tam w formie wskaźnika sezonowości małżeństw, a które potraktował jako dane pierwotne i pracowicie przeliczył na odsetki według miesięcy. Z kolei swoje dane dla Kut pozostawił nieprzeliczone do wskaźnika sezonowości małżeństw i obliczył zwykły wskaźnik struktury. Pominę tutaj szczegóły kwestii metody obliczania wskaźnika sezonowości, ale w skrócie porównuje on dwa wyniki - jeden wyrównany do miesięcy trzydziestodniowych, a drugi bez uwzględnienia różnej liczby dni w poszczególnych miesiącach, co ma wpływ na wyniki i interpretację wskaźnika. Taki sam błąd popełnił 
zresztą przy analizie sezonowości ślubów według dni tygodnia, również traktując wartość wskaźnika jako dane źródłowe (s. 111), jakkolwiek w tym przypadku przynajmniej nie wpływa to na uzyskane wyniki.

Rozważania na temat małżeństw powtórnych pomiędzy kawalerem a wdową ze względu na nikłą podstawę źródłową ( 25 przypadków w ciągu 68 lat) nie mają żadnego uzasadnienia analitycznego i są jedynie odchyleniem przypadkowym od tendencji głównej. Interesujące są natomiast uwagi na temat małżeństw endo- i egzogamicznych wyznaniowo oraz kwestii narzeczeństwa, przygotowania do ślubu, ceremoniału ślubnego. Ten fragment rozdziału jest dobrze napisany i świetnie zilustrowany tekstami źródłowymi; wprowadza czytelnika w ormiańską przeszłość obyczajową i religijną.

Rozdział IV, Potomstwo, już w trzecim zdaniu zmusza do sięgnięcia do Słownika języka polskiego po przeczytaniu passusu: „Połowę tamtejszej populacji ormiańskiej stanowili młodzieńcy do 19. roku życia”, lecz definicja młodzieńca, na przekór zmianom obyczajowym, pozostaje nietknięta i oznacza „młodego mężczyznę". Wynikałoby zatem z tego, że połowa populacji Ormian w Horodence w 1791 roku to mężczyźni w przedziale wiekowym 0-19, czemu przeczy nie tylko zdrowy rozsądek, ale i tabela numer 14 zamieszczona na stronie 133. Tabela ta zresztą jest źle sformatowana, liczby nie są wyrównane do prawego marginesu, różna jest też liczba miejsc dziesiętnych, przedziały otwarte powinny mieć inny zapis: „60 i >” oraz „65 i >”.

Analiza sezonowości urodzeń jest przeprowadzona nieprawidłowo, autor nie wysilił się i nie obliczył ani wskaźników sezonowości, ani struktury, jak miało to miejsc w przypadku małżeństw. Z kolei omówienie dzietności małżeńskiej to studium przypadków, których naliczyłem zaledwie 3. Zamiast przeprowadzić rekonstrukcję rodzin ormiańskich i omówić wyczerpująco problem, autor ograniczył się do znikomej egzemplifikacji, jak sądzę, najbardziej płodnych par. Dalej jest niestety jeszcze gorzej. Na stronie 142 zamieszczony został wykres numer 2, z którego można wyczy tać, jaki był „roczny rozkład chrztów” w katedrze ormiańskiej we Lwowie. Tytuł jest błędny, ponieważ nie jest to żaden roczny rozkład, lecz liczba chrztów w dziesięcioletnich przedziałach, zaczynających się zresztą nieprawidłowo od 6 na końcu zamiast 1, czyli prawidłowy przedział pierwszy to 1776-1780 (niepełny, można go było pominąć), 1781-1790, 1791-1800 itd. Można również zauważyć, że tytuł nie odpowiada przedstawionym liczbom, na końcu osi jest jeszcze jeden przedział o niewiadomym zakresie lat i wartości około 60 chrztów. Co ciekawe, kilka stron dalej, przy omawianiu liczby dni upływających od narodzin dziecka do jego chrztu, znów skonstruowano nieprawidłowo przedziały lat, tym razem kończąc na cyfrze 9, czyli uniemożliwiając porównanie wyników badań nawet w obrębie samej pracy. 
W dalszej części rozdziału omówione zostały urodzenia pozamałżeńskie (bardzo zresztą rzadkie u Ormian), ceremonie chrztu i bierzmowania oraz przeprowadzona została analiza nadawanych imion z podziałem na chłopców i dziewczęta w poszczególnych miejscowościach. Nie można się przy tym oprzeć wrażeniu, że im dalej autorowi od źródeł masowych, tym jego praca jest lepsza.

Rozdział V, Ormiańskie ognisko domowe, dostarcza wiedzy o rodzinie, ale w zupełnie inny sposób, niż czynią to monografie z zakresu demografii historycznej. Nie znajdziemy w nim typologii gospodarstw domowych Petera Lasletta czy analizy stanu cywilnego według wieku i podobnych metod analizy struktury rodzinnej. W zamian za to uzyskujemy wgląd w kwestie prawne funkcjonowania ormiańskiej rodziny oparte głównie na aktach sądowych, studiach rodziny w trakcie sprawy rozwodowej czy relacjach z bojów o spadek, a także opisy relacji rodzinnych w powiązaniu z prowadzeniem interesu. Konstrukcja dalszej części rozdziału - Między rodzina mieszczańska i szlachecka - nie jest przejrzysta. Przedstawione przykłady zaczynają niejako żyć własnym życiem i choć czyta się je znakomicie, to trudno się zorientować, jakie poglądy na temat prezentowanego materiału ma sam autor i czy uważa go za typowy dla ormiańskiej społeczności.

W ostatnim rozdziale, Śmierć i pogrzeb, drugi akapit niezbyt szczęśliwie zaczyna się od stwierdzenia, że ,śmierć w społecznościach przed transformacją demograficzną zawsze była nieprzewidywalna”. Śmiem twierdzić, że także w XXI wieku śmierć jest zdarzeniem nieprzewidywalnym, odsuniętym jedynie w czasie $\mathrm{z}$ powodu niższego prawdopodobieństwa wystąpienia tego zdarzenia $\mathrm{w}$ młodszym wieku. Dalej autor kontynuuje w tym samym tonie swe osobliwe rozważania, dając dowód ignorancji w dziedzinie demografii (i logiki): „W każdym razie dla ówczesnego człowieka śmierć i umieranie były zjawiskami zdecydowanie częstszymi niż ma to miejsce dzisiaj”. Otóż prawdopodobieństwo wystąpienia zdarzenia zgonu jednostki $\mathrm{x} w$ populacji y jest równe 1 zarówno 1000 lat p.n.e., jak i obecnie. Więcej ludzi w badanym przez F. Wasyla czasie nie umierało, lecz rodzice i krewni częściej byli świadkami tych zgonów, niż ma to miejsce współcześnie.

W dalszej części rozdziału przeprowadzono analizę sezonowości i przyczyn zgonów, szczególnie skupiając się na najmłodszych w przedziale 0-19 lat. Należy przyznać, że pomimo niskiego poziomu diagnostyki medycznej wymienione w pracy przyczyny dają pewien przybliżony obraz stanu zdrowia ówczesnej populacji oraz trapiących ją chorób. Odrębnie potraktowane zostały zgony osób młodych (0-19 lat) i będących w sile wieku (20-59 lat) oraz osób starszych (60 lat i więcej). Nie jest to powszechna praktyka w pracach demograficznych, tym bardziej że wyznaczenie wieku starczego jest dla epoki przedprzemysłowej zadaniem bardzo trudnym, gdyż aktywność zawodowa trwała w zasadzie do śmierci. Brak jest natomiast omówienia umieralności niemowląt, która jest bardzo 
czułym wskaźnikiem poziomu cywilizacyjnego i zamożności danej społeczności. W przypadku Ormian, aż prosiło się o ich porównanie z rzymskimi i greckimi katolikami. Próba analizy zgonów z powodu gruźlicy według miesięcy ze względu na małe liczebności w Stanisławowie i Kutach jest zupełnie niewiarygodna, podobnie jak i wykres numer 11 na stronie 246 (raz identyfikowany w tekście jako 10, a raz jako 11), który przedstawia dane z 14 (sic!) miesięcy - szkoda tylko, że dwa ostatnie dwukrotnie. Podobnie ma się rzecz z analizowaniem sezonowości zgonów (s. 252). Autor nie dość, że nie policzył wskaźników sezonowości, to jeszcze wskaźniki struktury są obliczone dla małych populacji. Interesujące spostrzeżenia natomiast znajdujemy w punkcie 3.2, w którym autor przedstawił pogląd, że właściciele gospodarstw często stali na ich czele aż do samej śmierci, a niektórzy przyjmowali także pod swój dach krewnych wymagających opieki. Teza ta - zdaniem autora - stoi w opozycji do poglądu C. Kukli, który stwierdził, że starość i pogarszające się zdrowie doprowadzały do rezygnacji z pracy zarobkowej. Autor jednak nie wziął pod uwagę faktu, że C. Kuklo miał na myśli głównie metropolitarną Warszawę wieku oświecenia, Kraków lub Wieluń, a nie miasteczka typu Kuty czy Horodenka.

Zgony w szpitalu w Horodence wydają się zaniżone - trudno uwierzyć, że w latach 1784-1824 zdarzał się najczęściej jeden zgon rocznie. Wydaje się, że pozostałe zgony mogły być rejestrowane w księgach greckokatolickich. Ponadto wykres numer 14 (s. 269) stanowi przykład złego zastosowania technik prezentacyjnych dla nielicznej zbiorowości. Wykres bowiem prezentuje jednostki, ale nie ukazuje żadnego trendu bądź struktury. W dalszej części znajdujemy niezwykle ciekawe fragmenty kronik o cudownych uzdrowieniach, których osobiście nie traktowałbym, jak chce autor, jako „kroniki chorób”, lecz raczej jako przejaw wiary i zabobonu ówczesnego społeczeństwa; trudno bowiem traktować opisane dręczenie nieszczęsnej niewiasty przez siedem lat przez złego ducha jako jednostkę chorobową.

Rozdział zamykają Chwila śmierci i Pogrzeb, dwa punkty ostatniej drogi, które zostały dobrze przedstawione i scharakteryzowane. Omówione zostały aspekty religijne i prawne pogrzebów w Galicji, co jest cenne tym bardziej, że reformy z końca XVIII wieku zmieniały wielowiekową tradycję pochówków, a także przygotowań do nich.

Pracę wieńczy krótkie, w zasadzie dwustronicowe Zakończenie, które nie jest podsumowaniem przeprowadzonych badań, a refleksją nad sprawami etnicznymi Ormian w Polsce. Zamieszczone zaś dalej Spis ilustracji, Spis tabel, Spis wykresów nie zostały opatrzone numerami stron, na których poszczególne elementy się znajdują, i jako takie nie spełniają dobrze swojej funkcji.

Jednoznaczna ocena pracy F. Wasyla jest bardzo trudna. Nie jest to na pewno „studium demograficzne”, bowiem z demografią historyczną i jej metodami 
analitycznymi książka ma niewiele wspólnego. Na początku publikacji można znaleźć przynajmniej próby wykorzystania metod ilościowych, ale im dalej, tym jest ich mniej, a te, które są, zastosowane zostały w sposób nieprawidłowy. Podstawowym błędem autora było wykorzystanie zbyt wątłej podstawy źródłowej, liczebność badanej zbiorowości jest w wielu wypadkach zbyt mała, żeby wyciągać jakiekolwiek wnioski. Mając to na uwadze, trzeba stwierdzić, że zarzuty pod adresem C. Kukli o to, że nie uwzględnił Ormian w swojej publikacji Demografia Rzeczpospolitej Przedrozbiorowej, są zupełnie nieuzasadnione, skoro populacja Ormian w czasach Rzeczpospolitej szlacheckiej była nieliczna i nie miała większego wpływu na procesy ludnościowe. Inaczej było, rzecz jasna, z rolą Ormian w gospodarce i kulturze Rzeczpospolitej.

Książka F. Wasyla nie jest, mimo wszystkich jej wad, bezwartościowa; zawiera niepublikowane wcześniej materiały źródłowe, które można z powodzeniem wykorzystać w badaniach genealogicznych, szereg interesujących informacji z zakresu życia codziennego Ormian, ich stosunków rodzinnych i tradycji. Napisana została także dobrą polszczyzną i czyta się ją z zainteresowaniem, a przytaczane przykłady zachowań społecznych zostały umiejętnie dobrane. Nie jest ona jednak studium demograficznym, lecz studiami nad społecznością Ormian w przedautonomicznej Galicji. 